\title{
BUSHFIRES IN THE KRACHI DISTRICT: THE SOCIO-ECONOMIC AND ENVIRONMENTAL IMPLICATIONS
}

\author{
J.M. Kusimi ${ }^{\Omega}$, J.W. Appati ${ }^{\Psi}$ \\ ${ }^{\Omega}$ Department of Geography \& Resource Development, University of Ghana, Legon. \\ Email: jmkusimi@ug.edu.gh \\ ${ }^{\Psi}$ Department of Geography \& Resource Development, University of Ghana, Legon.
}

Working Group, Theme or Special Session: VIII/1: Disaster Management

KEY WORDS: Bushfires, Fire severity, Krachi District of Ghana, Normalised Burn Ratio, Remote Sensing, Change Detection.

\begin{abstract}
:
Bushfires are becoming one of the environmental challenges confronting Ghana and increasingly it has become difficult for the Government to control it because this activity is deeply rooted in the socio-cultural and economic systems of the people. The effects of bushfire on rural livelihoods and on the ecosystem in Ghana are extensive and damaging. Bushfires have accelerated environmental degradation especially in the fragile savannah ecosystem, yet there is very little in the form of public education, published data and information concerning the frequency, intensity, duration and effects of bushfire on the environment and human welfare in Ghana. The study did a change detection of biomass cover using pre and post fire normalized burnt ratio of Landsat TM+ imageries of 2002 and 2003 to determine fire severity on vegetative cover. The socio-economic impact of this disaster was collected using social survey approaches such as interviews and focus group meetings. Some of the consequences of the bushfire include the burning of food stuffs, houses as well as domestic animals. The environmental impacts of these bushfires have been very devastating and these involve the lost of biodiversity (plants and animals) and the depletion of organic matter of the soil thus impoverishing the soils. The research found out that, the continuous prevalence of this activity was due to the laxity in the implementation of bye-laws regulating bushfire burning due to the lack of personnel and logistics to state agencies in the District to combat the problem.
\end{abstract}

\section{INTRODUCTION}

Bushfires are a common occurrence in the savannah ecological zones of Ghana. The savannah and grassland environments produce fine fuels that dry out rapidly at the end of the rainy season resulting in some of the most frequent firereturn intervals on Earth (Archibald et al, 2010). Moreover, human ignition and fire management are pervasive throughout Africa, because much of the population is not yet urbanised, and communal land management is common (Archibald et al, 2010). Wild land fire is an ecologically important disturbance factor in many ecosystems. While providing many benefits in fireadapted systems, catastrophic fire can cause severe ecosystem and watershed damage. Catastrophic fires modify ecosystems by removing vegetative cover, destroying leaf chlorophyll, charring stems and altering soil characteristics which increase the risk of severe erosion and the time required for ecosystem recovery (Epting et al, 2005; Miller and Yool, 2002). Information on within-burn variability is useful to ecologists and resource managers who want to understand fire's effects on ecosystem processes, for example, vegetation recovery and succession, and to plan post-fire rehabilitation and remediation. Such within-burn information may be estimated by visual examination of burned site conditions or by labour-intensive field measurements (Roy et al, 2006).

A number of approaches to the monitoring of biomass burning by remote sensing have been proposed over recent years (Eva and Lambin, 1998). The first option concerns the selection of a suitable indicator of biomass burning: smoke plumes, active fires; or burnt areas (Eva and Lambin, 1998). Remote sensing of burnt landscapes is made possible because of the physical changes such as canopy consumption, ground charring, and soil colour alteration that are associated with this disaster. Remote sensing is a useful tool for mapping the extent of the burn, understanding the biological responses due to differential surface heating (i.e. fire severity), and quantifying the extent and pattern of these burned areas (Eidenshink et al, 2007; White et al, 1996). These physical characteristics are detectable using sensors that can capture these attributes of landscapes. Fire has a significant effect on the reflective properties of the land surface due to vegetation removal, soil exposure, and soil colour alteration making the observation of fire severity by spectral data possible (Jakubauskas et al, 1990; Milne, 1986, cited in White et al, 1996). Pre-fire vegetation conditions also influence spectral classification of burn severity (White et al, 1996) by comparing it with post-fire conditions of the vegetation.

Several algorithms to identify and map burned areas have been developed (Miller and Thode, 2007; Miller and Yool, 2002; Roy et al, 2006), which give an indication of the total area burned by fire, and can be used to derive the season and frequency of fire (Archibald et al, 2010). Indices applied to burn mapping have included single date, post-burn and bi-temporal, pre- and post-burn approaches (Epting et al, 2005). Parameters used to estimate severity in the field include the condition and colour of the soil, amount of fuel consumed, resprouting from burned plants, blackening or scorching of trees, depth of burn in the soil, and changes in fuel moisture. Although several of these parameters may not be amenable directly to optical wavelength remote sensing, or may not be related in a linear way to reflectance, field-based measures of fire severity have been used to parameterize and assess fire severity maps created using optical wavelength satellite data (Roy et al, 2006). One index presented as a reliable means to map fire severity using remote 
sensing is called the normalized burn ratio (NBR), computed as the difference between near-infrared (NIR) and middle-infrared (MIR) reflectance divided by their sum (Roy et al, 2006). Though the near-infrared wavelengths in colour infrared photographs are useful in mapping vegetation mortality and soil moisture, it has been shown that mid-infrared bands (band $5=$ $1.55-1.75 \mathrm{Am}$ and band $7=2.08-2.35 \mathrm{Am}$ ) of Landsat Thematic Mapper (TM) contribute new information for classifying burn severity (White et al, 1996; Miller and Yool, 2002). Most researchers agree that fire severity is a measure of the amount of soil organic matter lost due to burning, decrease in surface cover, and volatilization or transformation of soil components to soluble mineral forms (Wells \& Campbell, 1979, cited by Miller and Yool, 2002). Research by Clark (2000, cited by Miller and Yool, 2002) has shown that pre- and post-fire differences of mid-infrared to near-infrared ratio (TM band 7/TM band 4) provided the highest contrast fire scar in comparison to TM band 4, PCA, Kauth-Thomas, NDVI, and MSAVI and, therefore provides the best enhancement for classifying changes due to fire. NBR values range between -1 and 1 as does the NDVI (Miller and Yool, 2002).

The capabilities of remote sensing and geographic information science (GIS) for mapping and monitoring changes in land are burgeoning (Alo and Pontius Jr, 2008). These techniques have been used increasingly as tools to measure the spatial and temporal patterns of land cover in many regions of the world (e.g. Musaoglu et al, 2005; Yuan et al, 2005 in Alo and Pontius Jr, 2008; Kusimi 2008; Yiran et al, 2011). However, mere monitoring of the land-cover changes does not necessarily shed light on the underlying causes of the land transformations. Scientists and policy makers need to understand the fundamental processes of land transformation in order to establish effective conservation and management strategies (Alo and Pontius Jr, 2008). In this regard, the study was undertaking using remote sensing and social survey techniques to access the causes and socio-economic and environmental effects of the annual bushfires on the people and the vegetative cover.

\section{STUDY AREA}

The study was conducted in the Krachi District which is located in the northern part of Volta Region in Ghana between latitude $7^{\circ} 20^{\prime}-8^{\circ} 20^{\prime} \mathrm{N}$ of the Equator and longitude $0^{\circ} 15^{\prime} \mathrm{W}-$ $0^{\circ} 24^{\prime} \mathrm{E}$ of the Greenwich Meridian. The District falls within two climatic regions, the tropical continental in the north and the wet semi-equatorial climate in the south with a mean annual rainfall of $115-150 \mathrm{~cm}$. Mean monthly temperatures range from $24^{\circ} \mathrm{C}$ in August to about $36^{\circ} \mathrm{C}$ in March. The southern part of the District is covered by the wet semi-deciduous forest whiles the northern sector the vegetation is the savannah grassland (Dickson and Benneh, 1995). The main drainage system in the district is the Volta Lake with a number of rivers draining into it (Fig.1). The lake covers the western part of the map and also partitions the district primarily into the Kete Krachi arm to the west and the Dambai arm to the east.

The District has experienced a steady growth in population from 29,980 (1970) to 65,530 (2000) (Ghana Statistical Service, 2002). Over $80 \%$ of inhabitants engage in agriculture which includes farming, fishing and pastoralism. Generally, farming is on subsistence level and crops grown include cereals like maize, sorghum and root crops such as yam and cassava. The environmental problem of the farming activity is shifting cultivation and bush fallowing which employ the slash and burn approach in preparing land for cultivation. Lands are often set ablaze by farmers to minimise the cost of preparing lands.

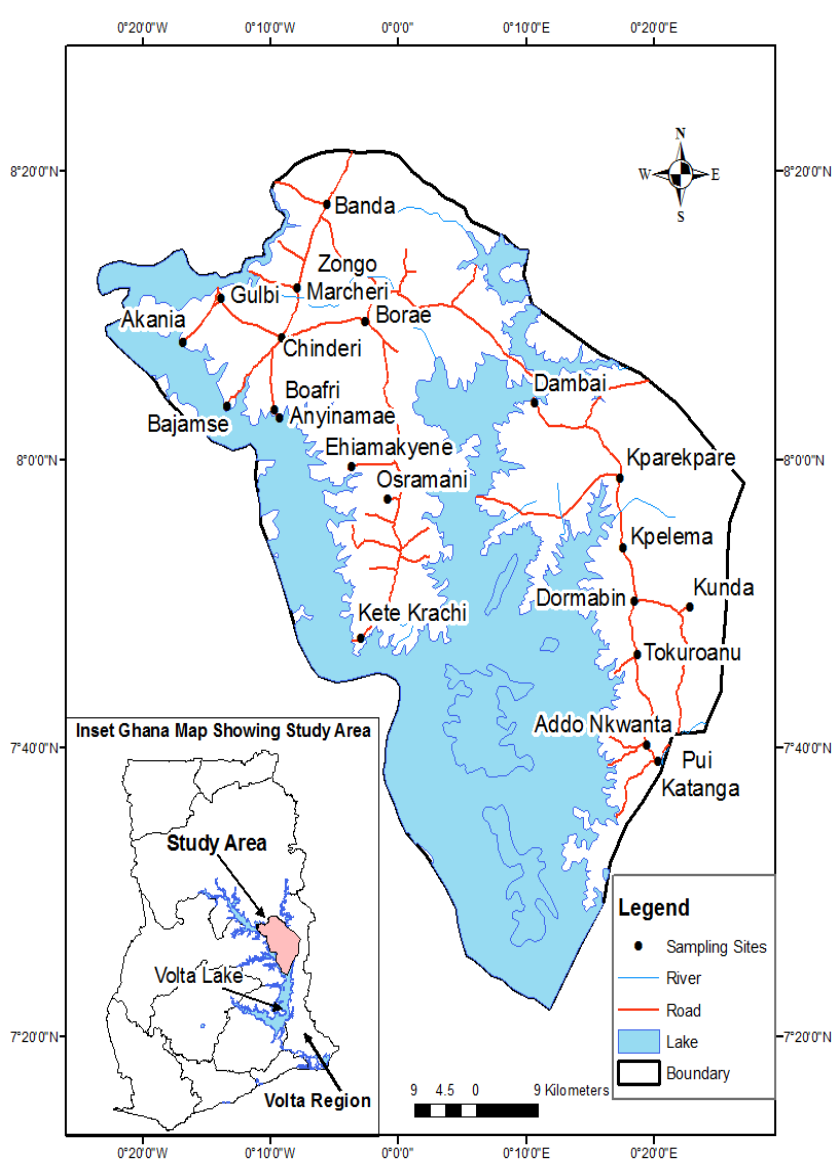

Fig.1: Map of the Study Area

\section{RESEARCH MATERIALS AND METHODS}

Field data collection involved interviews with opinion leaders such as chiefs, queen mothers, assemblymen and women, District Assembly staffs, Fire Service and National Disaster and Management Organization (NADMO) (e.g. Gangemi et al, 2003). A total of 102 respondents were interviewed in 17 towns and Table 1 illustrates the number of respondents selected from each community and Fig. 1 shows the spatial distribution of the communities. The District was divided into East Krachi and West Krachi and a simple random sampling method without replacement was used to select the communities (e.g. Kusimi and Yiran, 2011). The number of people selected in each community was a function of population size. Focus groups discussions were also organized among farmers and Fulani herdsmen (e.g. Gangemi et al, 2003). Proceedings were recorded and later transcribed to augment information from interviews.

Satellite images employed for the determination of change in vegetative cover/fire severity are Landsat ETM+ of 2002 and 2003. These were the only free downloadable scenes of the study area. The study area falls into two scenes of row and path 054/193 and 055/193. The images were downloaded from the Global Land Cover Facility website www.glcf.org and glovis.usgs.gov. Landsat ETM+ 2002 images were acquired on 
Table 1: Number of Respondents Selected for the Questionnaire Administration.

\begin{tabular}{|l|l|l|}
\hline Town & Population & $\begin{array}{l}\text { No. } \\
\text { Respondents }\end{array}$ \\
\hline Dambai & 13,768 & 25 \\
\hline Kete Krachi & 9,285 & 10 \\
\hline Banda & 6,730 & 5 \\
\hline Borae & 4,108 & 6 \\
\hline Pui Katanga & 3,381 & 5 \\
\hline Tokuroanu & 3,271 & 5 \\
\hline Chinderi & 2,815 & 4 \\
\hline Gulbi & 2,779 & 4 \\
\hline Bajamse & 2,290 & 4 \\
\hline Kunda & 2,131 & 4 \\
\hline Osramani & 1,950 & 4 \\
\hline Boafri & 1,773 & 4 \\
\hline Akania & 1,637 & 3 \\
\hline Ayinamae & 1,576 & 3 \\
\hline Ehiamakyene & 1,572 & 3 \\
\hline Dormabin & 1,500 & 3 \\
\hline Zongo Marcheri & 1,432 & 4 \\
\hline Kparekpare & 1,237 & 2 \\
\hline Addo Nkwanta & 1,178 & 2 \\
\hline Kpelema & 1,149 & 2 \\
\hline Total & $\mathbf{1 5 9 , 9 2 5}$ & $\mathbf{1 0 2}$ \\
\hline Source: Ghan Stat & & \\
\hline
\end{tabular}

Source: Ghana Statistical Service, 2000

$10^{\text {th }}$ December whiles those of 2003 were on $27^{\text {th }}$ January. All the images were of resolution $30 \mathrm{~m}$ and processed to L1T before acquisition. The 2002 images (054/193) and (055/193) had cloud cover of $16 \%$ and $27 \%$ respectively. The images were cropped to size using geographical coordinates of the study area. Landsat ETM+ 2002 image was used as the pre-fire image and Landsat ETM+ 2003 as the post-fire image. Normalised burn ratio (NBR) of each image was determined using the following algorithm in Idrisi (Eidenshink et al, 2007; Miller and Yool, 2002):

$N B R=\frac{\text { band } 4-\text { band } 7}{\text { band } 4+\text { band } 7}$

Afterwards, scenes of the same year were mosaic into one image (Figs.3 and 4). The post-fire NBR image is differenced from the pre-fire image to obtain changes in vegetative cover denoted as dNBR (Fig.5) (Eidenshink et al, 2007).

\section{RESULTS AND DISCUSSION}

With increasing encroachment of human populations into the wilderness there is also an increased threat to private and public infrastructure from wildfire effects. Not only are natural view sheds and recreational areas at risk of disappearing for decades or even centuries, but human lives, property, and livelihoods are at risk (Miller and Yool, 2002).

\subsection{Causes of bushfires in the District}

One of the critical environmental problems facing the Krachi District and for that matter Ghana in the dry season is bushfire and there are several reasons explaining the prevalence of this practice in the study area. It must also be stated that, the extent and intensity of these fires are greater in the savannah ecosystems where this study took place especially during harmattan seasons as compared to the forest ecosystems. Bushfires in the Krachi District revolves around the socioeconomic activities of the people such as farming and cattle rearing. Fire is widely accepted throughout the country as being a valuable tool in the management of natural vegetation. Field survey indicated that about $60 \%$ of bushfires are caused by peasant farmers, $30 \%$ attributed to pastoralists, $6 \%$ to ward-off snakes and $4 \%$ due to the traditional festivals of the people (fire festival etc)

Fires are used to clear lands for farming especially during the dry season. This is because it is a cheaper, faster and easier method of clearing lands. Though some farmers do it intentionally, others create fire belts, but in the dry season, the harmattan winds could be too strong and cause spill over to unintended lands.

The study also revealed that, the need to get fresh regrowth of grass for cattle grazing by Fulani herders promotes bush burning. During the dry season, local cattle herders and immigrants from neighbouring countries, Mali and Burkina Faso called the Fulani set ablaze the vegetation to promote early regrowth of fresh pasture for the animals. Sometimes village folks are paid some token fees by these nomadic herdsmen to set the dry vegetation ablaze during the dry months of November to March while they move southwards to find fresh vegetation for the cattle. The herdsmen return with their cattle around April and May by which time the vegetation might have resprouted by the early rains of April and May. Most herders believe that bush burning improves the palatability and nutritional value of grasses and trees for grazing (NsiahGyabaah, 1996). The vegetation is also set ablaze when the headsmen notice that their heads of cattle are going to fall into the hands of harmful pests and insects such as ticks and tsetse flies.

Snake bites are a serious health problem confronting most communities and they resort to early burning of the vegetation to control the number of snakes in the ecosystem. This is due to the fact that, though snake bite patients entitle to free medical care at the health centres, however these health centres in most cases are inaccessible due to either the poor nature of the road, shortage of anti-snake serums and the distance to health post is sometimes far.

Hunting is also another important livelihood activity in the savannah ecosystems especially in the dry season; most people go on hunting expeditions and set fires to drive out game to kill because meat forms one of the primary sources of protein amongst the people. Accidental causes of wildfires involved cooking in the farms, palm wine tapping, charcoal burning, honey extraction and cigarette smoking.

From the respondents, it was noted that people are aware of PNDC Law 227 which prohibits the setting of bushfires. However, the enforcement of this legislation in the rural areas has been ineffective because state agencies; National Fire Service, National Disaster and Management Organization, Wildlife and Forestry Commission charged with controlling the menace are under staffed and ill-equipped to tackle the problem of bushfires.

\subsection{Effects of bushfires in the District}

The impact of the annual burning of the wild is discussed in two thematic areas; the socio-economic and environmental effects. 


\subsubsection{Socio-Economic Impacts}

Social survey conducted indicated that bushfires have brought untold hardships to individuals or sometimes a whole community/household either in the form of lost of lives or property. There are numerous cases of part or whole communities being raised down by fires (Fig.2). These fires sometimes burn maize, cassava and rice farms, cashew, mango and other tree plantations. Harvested farm produce in silos on the farms or at home are sometimes affected by spill over wildfires. As shown in Fig.2, the number of reported cases of fire outbreaks, number of affected victims and households has generally been on the increase since 2002. Estimates of property lost in major wildfires ranges into several thousands or millions of Ghana cedis. Human lives and that of domestic animals are sometimes lost in these fires. Electrical poles and other installations are sometimes burnt in these fires disrupting power supply to the communities. The disruption in electricity supply negatively affects the socio-economic activities of residents engaged in the sale of food, meat, fish, beverage and drinks as their stock go bad and has to be discarded at a great cost to them because their businesses are not insured. Also domestic food is destroyed. Other small scale artisanal industries such as welding are affected. The local people said it is hard to put a monetary figure on the loss of income associated with this annual bush fire disasters because they are small scale businesses and do not keep records of sales, but admitted that the financial burden has been enormous.

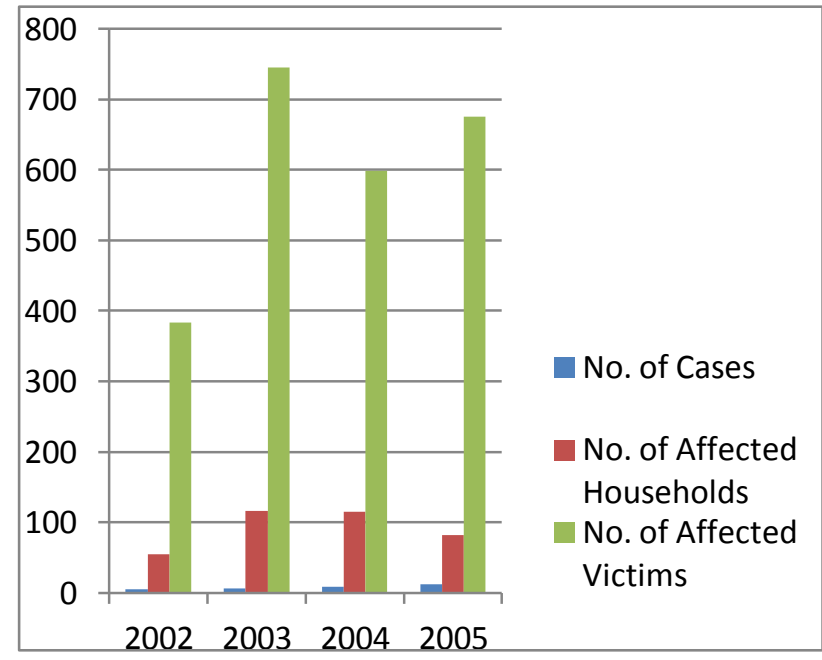

Fig. 2: Statistics on Bush Fire Disaster Records from 2002-2005 Source: NADMO - Krachi District, 2006

Operations of health facilities are also retarded when the power supply is disrupted by burnt electric poles which have great implication on health delivery. When houses are burnt, victims are rendered homeless and their household properties destroyed. Families are often accommodated by relatives, friends, tents or in public places such as schools/churches. Affected victims indicated that they are often traumatised and psychologically disturbed by these unfortunate events. Due to the cold weather of the harmattan winds of the season, families who are accommodated at public places are mostly exposed to health hazards such as flu and pneumonia because they have to sleep on bare floors which are sometimes not cemented and dusty. The Government through the National Disaster and
Management Organization and the District Assembly spends huge sums of money on relief items (e.g. food, sleeping mats, blankets, mattresses, buckets, cooking utensils etc) for such people and in rehabilitating the communities by assisting with building materials such as cement and roofing sheets when these disasters occur.

\subsubsection{Environmental impacts of Bushfires: Land cover Change \& Bio-diversity Lost.}

The environmental consequences of these extensive fire damages include the burning of plants resulting in the reduction of plant cover which affects the habitat of wild life, burning of tree plantations, and the destruction of farms.

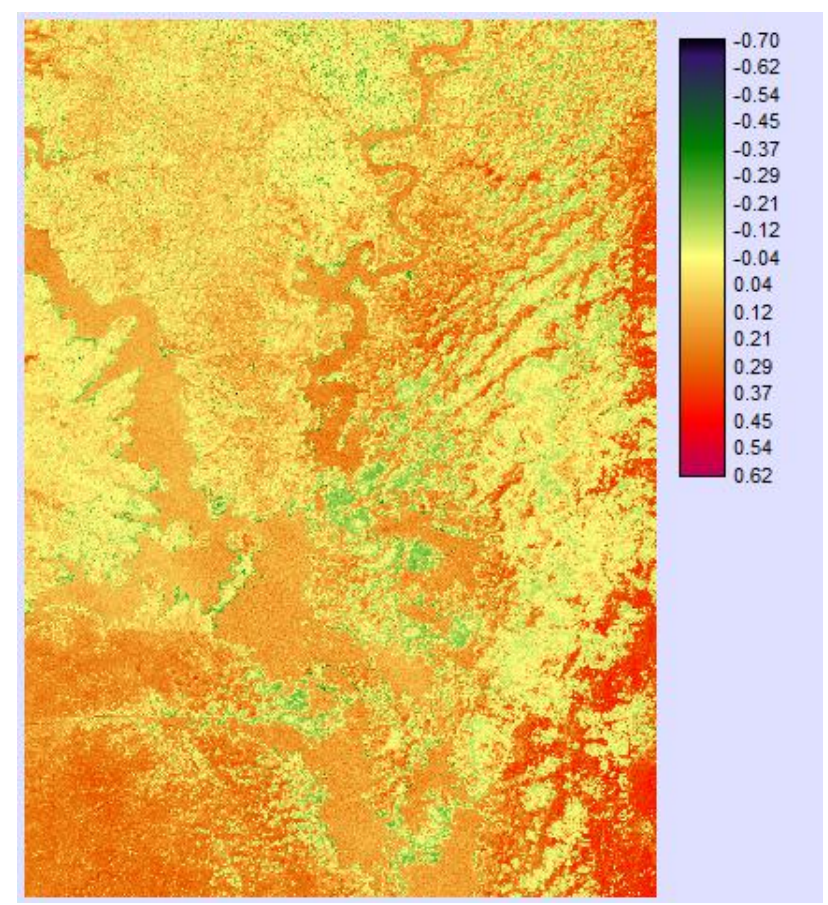

Fig.3: NBR of Pre-fire Landsat ETM+ 2002

Figs. 3 and 4 show the NBR images of 2002 and 2003. In prefire images, vegetated areas have values greater than zero and areas of bare ground or rock have values less than zero (Miller and Yool, 2002). However, in fig. 3 much of the greens which are associated with negative values are cloud cover. The real NBR values ranges from 0.04 to 0.62 . In post-fire images, increasing fire severity is associated with decreasing values (Miller and Yool, 2002). As shown in Fig.4, except at the eastern corridor from Dambai to Pui Katanga fire severity is intense within the locality with intensity increasing from -0.02 to -0.78. Negative values of $\mathrm{dNBR}$ indicate a positive vegetation response (growth) and positive values indicate a negative vegetation response (mortality) (Eidenshink et al, 2007).

Generally, the whole area studied indicates a reduction in vegetative cover after bush fire events in 2003 with values ranging from 0.04 to 1.04 (Fig.5). Areas of re-growth in vegetation are concentrated in the eastern part of the District which has three forest reserves; Chair River, Asuokoko River and Kabo River Forest Reserves. These areas are under the protection of Ghana Forestry and Wildlife Services Division and this account for the growth in vegetation of this section of the area. 


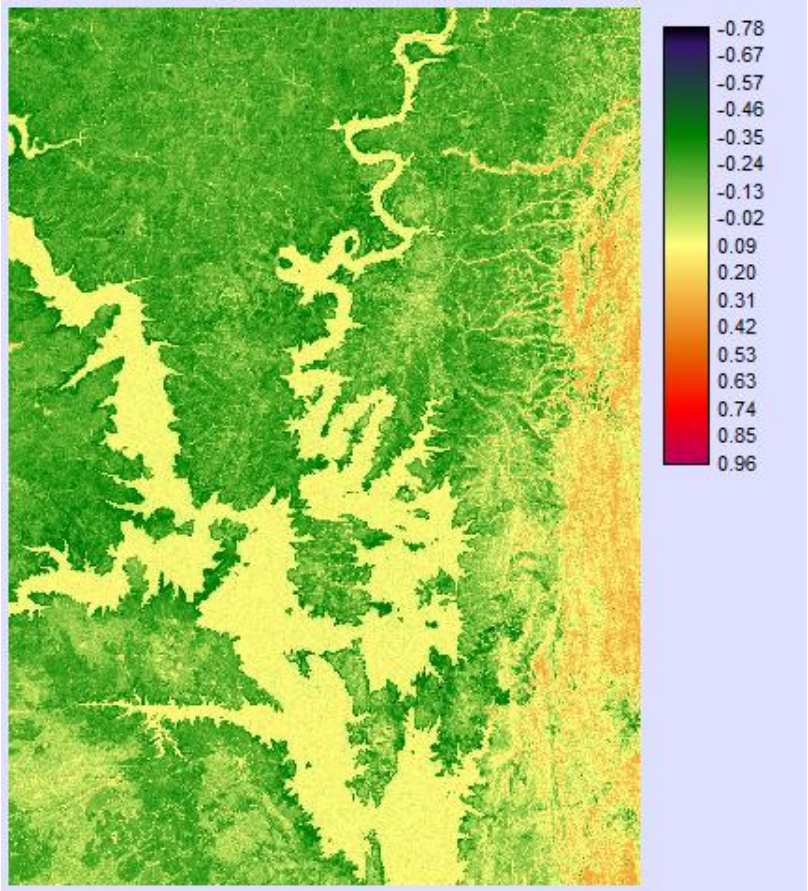

Fig.4: NBR of Post-fire Landsat ETM+ 2003

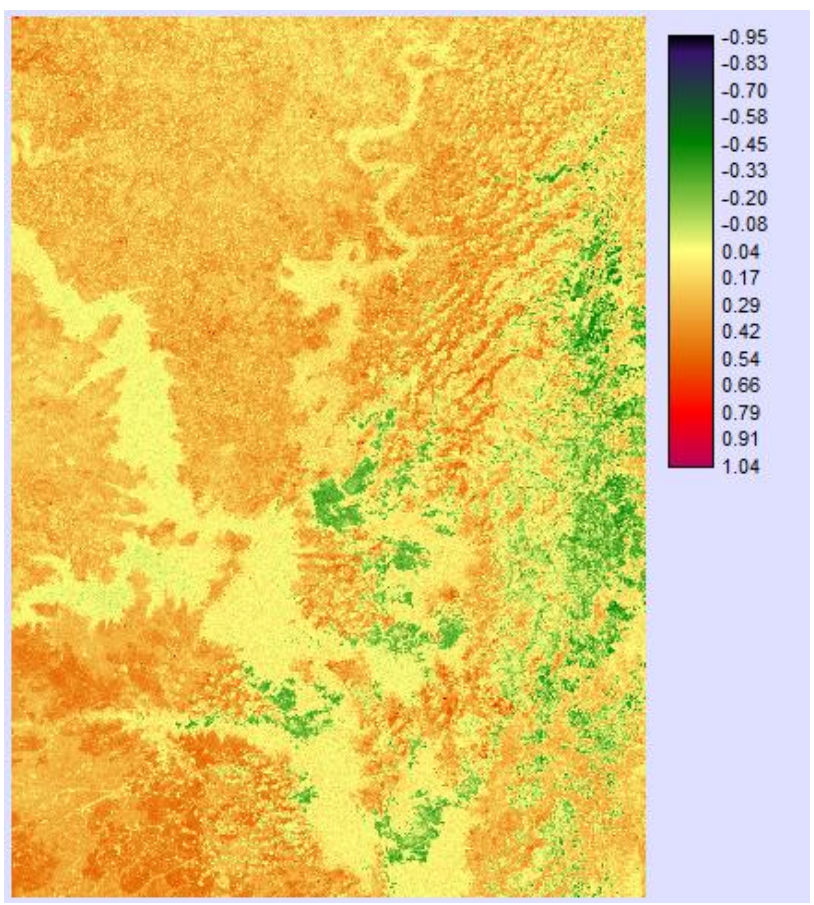

Fig.5: A dNBR image indicating change in Vegetative cover

Studies have shown that farm fires which heat the soil to $200^{\circ} \mathrm{C}$ are actually beneficial because they increase nutrient availability to plants (potash from the burnt ash). However, temperatures in excess of $400^{\circ} \mathrm{C}$ are detrimental because they completely destroy the soil organic matter and reduce the cation exchange capacity. They also cause the volatilization of soil nutrients. The effects can be damaging to soil structure and plant stability. A deterioration of the soil structure hinders the quick regrowth of plants and facilitates crust formation. This is particularly common during the months of January to March when the vegetation is completely dried. Also fires which burn large tree trunks or destroy heaped plant material at confined spots can also reach temperatures in excess of the threshold value resulting in serious damage to soil micro-organisms such as termites, earth worms and rodents (Nsiah-Gyabaah, 1996).

Literature has it that indiscriminate bush burning has been one of the major factors in the change of forest to woodland, woodland into savannah and savannah to shrub land. The Sudan and Guinea grasslands are anthropogenic climax communities maintained by grazing, bush burning and crop cultivation, and they will revert to scrub and then woodland and forest if these controlling factors are removed. Fire produces immediate effects on aerial vegetation, which become evident by total plant death or by partial destruction. High canopy trees may escape ground fires because the vertical discontinuity of fuel prevents fire reaching the canopies. Plant composition is also affected by fire in an indirect manner through species substitution (NsiahGyabaah, 1996).

\section{CONCLUSION}

The battle against bush fires in the district is far from over. The people's way of life and their economic well being are closely associated with the setting of wildfires in the District. Other factors include weak legislative instruments as well as the lack of political will on the part of the government to prosecute the policy of anti-bushfires. These acts are not only negatively affecting the economic activities of the local people in the form of the destruction of their food, houses as well as domestic animals, but it is also destroying the physical environment. Plants and animals are destroyed by the wildfires resulting in a reduction in biomass cover. Discussions with some chiefs, queen mothers and assemblymen and women revealed that they are unhappy with this state of affairs and suggested the promotion and intensification of anti-bushfire education through local chiefs, opinion leaders and school children, equipping agencies and the rearing of animals such as grass cutter and other small ruminants to serve as a source of protein to the people will help curb the menace.

\section{REFERENCES}

Alo, C. A., and Pontius Jr, R. G., 2008. Identifying systematic land-cover transitions using remote sensing and GIS: the fate of forests inside and outside protected areas of Southwestern Ghana. Environment and Planning B: Planning and Design 2008, Vol. 35, pp.280-295.

Archibald, S., Scholes, R. J., Roy, D. P., Roberts, S., and Boschetti, L., 2010. Southern African fire regimes as revealed by remote sensing. International Journal of Wild land Fire, 19, pp.861-878.

Diaz-Delgado, R., Lloret, F., and Pons, X., 2010. Influence of Fire Severity on Plant Regeneration by Means of Remote Sensing Imagery. International Journal Of Remote Sensing, Vol.24, No.8, pp. 1751-1763.

Dickson, K.B., and Benneh, G., 1995. A New Geography of Ghana. Longman, London, pp.21-33. 
Eidenshink, J., Schwind, B., Brewer, K., Zhu, Z., Quayle, B., and Howard, S., 2007. Project for monitoring trends in burn severity. Fire Ecology, Special Issue Vol. 3, No. 1, pp.3-21.

Epting, J., Verbyla, D., and Sorbel, B., 2005. Evaluation of remotely sensed indices for assessing burn severity in interior Alaska using Landsat TM and ETM+. Remote Sensing of Environment, 96, 328-339.

Eva, H., and Lambin, E. F., 1998. Remote Sensing of Biomass Burning in Tropical Regions: Sampling Issues and Multisensor Approach. Remote Sensing of the Environment, 64: pp.292-315.

Gangemi, M., Martin, J., Marton, R., Phillips, S., and Stewart, M., 2003. Socio-Economic Impact of Bushfires on Rural Communities and Local Government in Gippsland and North East Victoria. A Report Submitted to Timber Towns Victoria A Local Government Association.

Ghana Statistical Service, 2002. 2000 Population and Housing Census. Ghana Statistical Service, Accra.

Kusimi, J.M., 2008. Assessing Land use and Land cover Change in the Wassa West District of Ghana Using Remote Sensing. Geojournal, 71, pp.249-259.

Kusimi, J. M., and Yiran, G. B., 2011. Application of Local Knowledge in Land Degradation Assessment in the Bawku East Municipality. Ghana Journal of Geography, Vol.3, pp.88-125.

Miller, J. D., and Thode, A. E., 2007. Quantifying burn severity in a heterogeneous landscape with a relative version of the delta Normalized Burn Ratio (dNBR). Remote Sensing of Environment, 109, pp. 66-80.

Miller, J. D., and Yool, S. R.., 2002. Mapping forest post-fire canopy consumption in several overstory types using multitemporal Landsat TM and ETM data. Remote Sensing of Environment, 82, pp. 481-496.

Nsiah-Gyabaah K., 1996. Bushfires in Ghana. IFFN No. 15, pp. 24-29.

Roy, D. P., Boschetti, L., and Trigg, S. N., 2006. Remote Sensing of Fire Severity: Assessing the Performance of the Normalized Burn Ratio. IEEE Geoscience and Remote Sensing Letters, Vol. 3, No. 1, pp.112-116.

White, J. D., Ryan, K. C., Key, C. C., and Running, S. W., 1996. Remote Sensing of Forest Fire Severity and Vegetation Recovery. Int. J. Wild land Fire, 6(3), pp.125-136.

Yiran, G. B., Kusimi, J. M., and Kufogbe, S.K., 2011. A Synthesis of Remote Sensing and Local Knowledge Approaches in Land Degradation Assessment in Bawku East District. Ghana. International Journal of Applied Earth Observation and Geo-information, 14, pp.204-213.

\section{ACKNOWLEDGEMENT}

I wish to thank the University of Ghana - Legon for supporting me financially with a conference grant to enable me attend the XXII ISPRS Congress in Melbourne, Australia to present this paper. 